\title{
ВПРОВАДЖЕННЯ БОЛОНСЬКОГО ПРОЦЕСУ У РЕФОРМУВАННІ НАВЧАЛЬНО-МЕТОДИЧНИХ ПІДХОДІВ НА КАФЕДРАХ ХІРУРГІЇ
}

\author{
П. Д. Фомін, П. В. Іванчов, О. В. Заплавський \\ Національний медичний університет імені О. О. Богомольия, м. Київ
}

\section{INTRODUCTION OF BOLOGNA PROCESS IN REFORMATION OF EDUCATIONAL AND METHODICAL APPROACHES AT DEPARTMENTS OF SURGERY}

\author{
P. D. Fomin, P. V. Ivanchov, O. V.Zaplavskyi \\ National Medical University by O. O. Bohomolets, Kyiv
}

\begin{abstract}
У статті описано особливості впровадження Болонського процесу у реформуванні навчально-методичних підходів на кафедрах хірургії.

The article adduces the peculiarities of introduction of Bologna process in reformation of educational and methodical approaches at departments of surgery.
\end{abstract}

Ветуп. Для сучасного стану розвитку національної вищої освіти характерні модернізація і реформування, спрямовані на приєднання до Болонського процесу з метою входження в Свропейський освітній і науковий простір.

Болонський процес - це здійснення структурного реформування вищої освіти, зміна освітніх програм, форм і методів навчання, контролю й оцінювання навчальних досягнень студента для підвищення якості освіти, можливості випускників вищих навчальних закладів працевлаштуватися на європейському ринку праці.

Упродовж останнього десятиріччя Україна наполегливо наближається до європейських стандартів у галузі освіти. Геополітична спрямованість сучасного цивілізованого процесу визначається його глобалізацією, природним зростанням значущості гуманітарної сфери, високими інформаційними технологіями. Стратегія сучасного навчання студента повинна стати віч-на-віч із проблемами конкурентоспроможності та використання нових технологій.

Основна частина. Одним із найважливіших завдань, які стоять перед вищими навчальними медичними закладами України, $є$ підготовка лікарів згідно 3 кваліфікаційною характеристикою із належним рівнем знань та практичних вмінь і навичок.

3 цією метою у Національному медичному університеті імені О. О. Богомольця для студентів створе- но сучасну навчально-методичну, науково-технічну i клініко-лабораторну бази, якими разом з українськими студентами користуються студенти із більш як 60 країн світу: Азії, Африки, Свропи, Америки. Викладання проводиться українською, російською та англійською мовами. У підготовці майбутніх лікарів на клінічних кафедрах важливим моментом є поєднання теоретичної підготовки студента, складовими якої слугує лекційний матеріал, самопідготовка 3 використанням базових підручників, методичних розробок, джерел всесвітньої мережі “Internet”, навчальні фільми із алгоритмами практичних навиків, що створені викладачами кафедр. Програмний курс вивчення хірургічних хвороб займає чільне місце у формуванні в студентів “скелета" хірургічних знань та практичних навиків, становлення у них клінічного мислення та професійної майстерності.

На кафедрах хірургії студенти вивчають догляд за хворими, оволодівають основними методами хірургічної пропедевтики, засвоюють базові знання усіх нозологічних форм у структурі захворювань органів черевної та грудної порожнин, середостіння, серцево-судинної та ендокринної систем. Саме на хірургічних кафедрах у студентів формується клінічне мислення на основі знань окремих нозологій хірургічної науки у поєднанні із оволодінням проведення хірургічних маніпуляцій діагностичної та лікувальної спрямованості. 
Під час написання навчальної історії хвороби студенти вчаться проводити диференційну діагностику і тим самим обгрунтовувати діагноз, визначати наступну лікувальну тактику із обгрунтуванням показань до проведення, термінів та типу хірургічних втручань залежно від клініко-морфологічних особливостей нозологічної форми та наявності і вираженості розвитку ускладнень.

Практичні заняття з хірургії проводяться в клініках, котрі знаходиться на базах хірургічних відділень клінічних лікарень м. Києва. Заняття на кафедрах хірургії проводяться за методикою єдиного дня. Структурно заняття поділені на 3 частини:

1. Контроль вхідного рівня знань.

2. Основна частина заняття.

3. Контроль вихідного рівня знань.

Контроль вхідного та вихідного рівнів знань здійснюється шляхом проведення тестового контролю згідно з кафедральними навчально-методичними розробками, які щорічно оновлюються та доповнюються згідно з затвердженими навчальними програмами.

Основна частина заняття, що складає 80 \% навчального часу, проводиться в навчальній кімнаті 3 викладачем, маніпуляційних кабінетах, біля ліжка хворого, в перев' язочних, операційній, приймальному відділенні, лабораторіях і кабінетах функціональної та інструментальної діагностики. Професорськовикладацький склад хірургічних кафедр залучає до проведення практичних занять аспірантів, клінічних ординаторів і лікарів-ординаторів хірургічних відділень, що наближає студентів до реального лікувального процесу у хірургічних клініках і допомагає їм в самостійній роботі і доведенні практичних дій до рівня навиків. На кафедрах студенти залучаються до виготовлення унаочнень навчального процесу, роботи в студентському науковому гуртку, де вони роблять перші кроки у власних наукових пошуках, дослідженнях та відкриттях.

На семінарському занятті здійснюється контроль знань студентів за допомогою опитування, з використанням комп'ютерів, мультимедійного забезпечення, таблиць, схем, малюнків.

Тестовий контроль знань та вмінь студентів розпочинається із задач множинного вибору, що входять до стандартизованого державного тестового іспиту “Крок” відповідного рівня навчання.

Нами проведено моніторинг засвоєння матеріалу 3 хірургії студентами III - VI курсів, який включав аналіз ефективності сприйняття різних джерел інформації у вигляді письмового опитування та анкетування.

До інформаційних джерел включили:

1. Лекції.

2. Самостійне вивчення матеріалу: а) підручники; методичні вказівки; б) мультимедійні джерела; в) мережа "Internet".

3. Аутовізуальна інформація.

4. Навчальні відеофільми.

5. Практичні навики: робота біля ліжка хворого, в маніпуляційній, в перев' язочній, операційній, чергування в клініці по швидкій допомозі.

Вивчивши та проаналізувавши отриману інформацію, ми одержали дані, які можна представити у вигляді діаграми (рис. 1). Найбільший відсоток знань студенти отримували від самостійної роботи з літературою, методичними вказівками, інформаційними носіями 3 мережі “Internet" - 35 \%, практичні навики $25 \%$, навчальні відеофільми - $25 \%$, лекції - $10 \%$, аутовізуальна інформація - 5 \%.

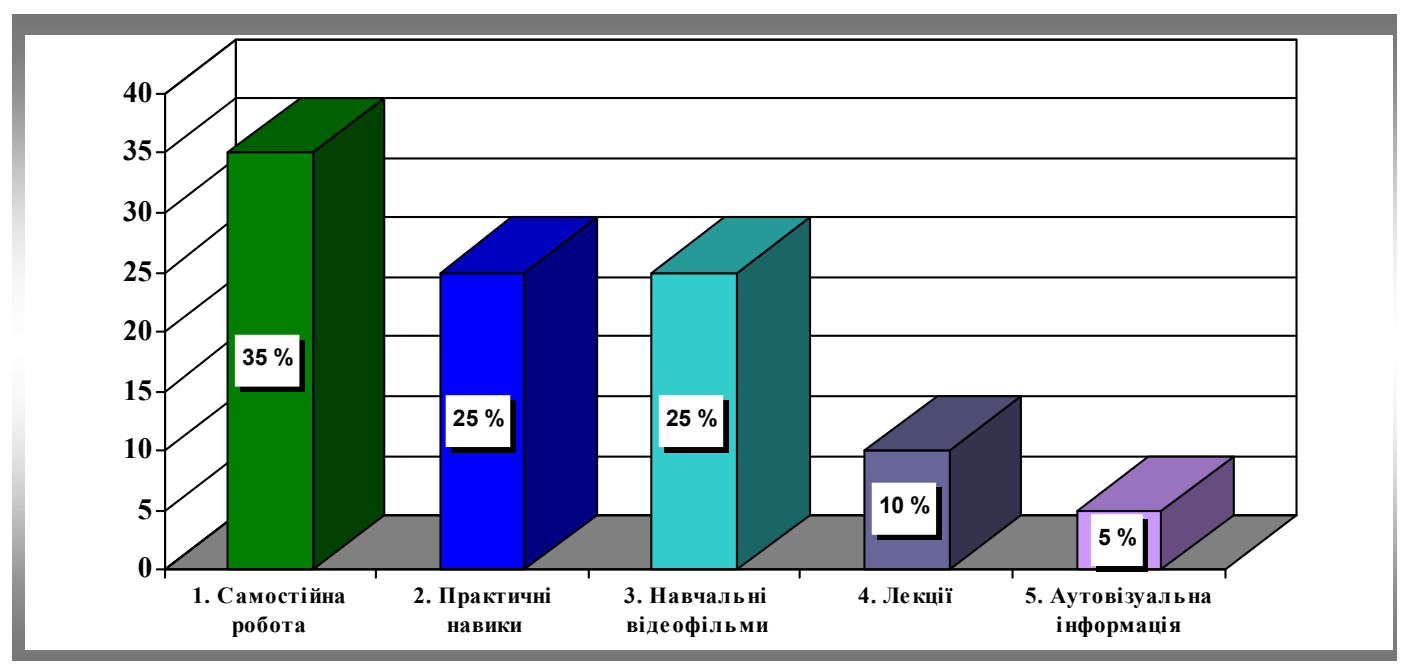

Puc. 1. Питома вага засвоєння матеріалу залежно від виду інформаційних джерел. 
Висновок. Досвід роботи кафедр хірургії Національного медичного університету імені О. О. Богомольця свідчить, що в комплексному підході до організації засвоєння знань і практичних навичок студентами III - VI курсів слід використовувати як традиційні методи навчання, так і сучасні інформаційні технології, включаючи мультимедійне забезпечення, навчальні відеофільми з алгоритмами практичних на-

\section{Література}

1. Вища освіта України і Болонський процес : навчальний посібник / [авторський колектив: М. Ф. Степко, Я. Я. Болюбаш, В. Д. Шинкарук та ін.]; за редакцією В. Г. Кременя. - Тернопіль : Навчальна книга - Богдан, 2004. - 384 с.

2. Годлевський А. І. Самостійна робота студентів в ургентній хірургічній клініці / А. І. Годлевський, О. О. Жупанов // Матеріали VI Всеукраїнської конференції завідувачів кафедр загальних хірургій медичних вузів України (Вінниця, 21-22 травня, 1998). - Вінниця, 1998. -С. 12 - 13. вичок, джерела мережі “Internet”, а при визначенні якості рівня засвоєння матеріалу - тестові завдання множинного інтегрованого іспиту “Крок” відповідного рівня навчання. Обов'язковим етапом при цьому $\epsilon$ дієва консультативна допомога професорсько-викладацького складу хірургічних кафедр і кваліфікованих лікарів-ординаторів хірургічних відділень клінічних лікарень м. Києва.

3. Методологічні аспекти активізації самостійної позааудиторної роботи студентів / Л. Я. Ковальчук, М. Д. Бех, А. Д. Беденюк [та ін.] // Актуальні питання оптимізації навчально-виховного процесу у медичному вузі : матеріали конференції. - Тернопіль, 1998. - Ч. II. - С. 17-20.

4. Кузнецова Л. В. Управление самостоятельной деятельностью студентов / Л. В. Кузнецова // Спеціаліст. - 1996. № 5. - C. 15-16. 